\title{
Effect of global change on maize production in the Argentinean Pampas
}

\author{
José M. Paruelo*, Osvaldo E. Sala \\ Departamento de Ecología, Facultad de Agronomia, Universidad de Buenos Aires, Av. San Martín 4453, 1417 Buenos Aires, \\ Argentina
}

\begin{abstract}
We analyzed the disect effect of enhanced $\mathrm{CO}_{2}$ concentration and the oftect of expected clumate change on the production of maze Zed mas $L$ in the Argentine Rolling Pampas Marize yield was simulated using the CERES Maize model. Clmate change scenamos for double CO, were genelated by 3 widely used Global Circulation Models (GCMs). Simulation analysis indicated a decrease in maize yield between 20 and 25 ". according to the GCM chosen. "The 36 G $\mathrm{A}$ is presisted an increase in temperature and precipitation, manly during summer months. Yiflat reduction was mainly the result of the shortening of the growing cycle. The direct effect of $\mathrm{CO}$, ontanceminent did not compensate the reduction in yield associated with the shortening of the growing season. The proportional reduction in yield was higher under nutrogen stress condition than without nitrogen stress. Adaptive strategles may compensate for redured yjeld. Sowing date needs to be moved forward 15 to 30 (l) to reach temperatures similat to the present. Modification of the grain fillung duration coefficient in the crop model compensated yield reduction, suggesting that now cultivars may be a good way of oftsetting the effects of global change
\end{abstract}

\section{INTRODUCTION}

The rapid increase of the $\mathrm{CO}_{2}$ concentration in the atmosphere since the beginning of the century has been clearly documented (Schneider 1989). Increases in $\mathrm{CO}_{2}$ concentration have large effects on the behavior of plants by decreasing stomatal conductance and increasing water use efficiency (Mooney et al. 1991). Field experiments have suggested that the increase in carbon fixation as a result of $\mathrm{CO}_{2}$ fertilization is largely influenced by the availability of water and nutrients. Resource-limited sites such as tundra had a small response to $\mathrm{CO}_{2}$ fertilization (Tissue \& Oechel 1987). On the other hand, marshes where nutrients and water are abundant showed a larger increase in photosynthesis as a result of doubling $\mathrm{CO}_{2}$ concentration (Ziska et al. 1990).

\footnotetext{
- Current temporary address: Department of Rangeland Ecosystem Science, Colorado State Unıversity, Fort Collıns, Colorado 8()523, USA
}

An increase in $\mathrm{CO}_{2}$ concentration in the atmosphere also has an indirect effect upon vegetation through changes in climate. There is agreement among scientists that an increase in $\mathrm{CO}_{2}$ and other greenhouse gases in the atmosphere will result in an increase in global temperature (Ramanathan 1988). Global Circulation Models, GCMs (Hansen et al. 1983, Manabe \& Wetherald 1987, Wilson \& Mitchell 1987), are excellent tools to explore geographical differences in the effects of $\mathrm{CO}_{2}$ increases.

The direct and indirect effects of an increase in $\mathrm{CO}_{2}$, which account for a large fraction of what is known as global change, may have profound effects upon vegetation. Studies have suggested that the location of major natural vegetation types as well as of major croplands may shift as a result of global change (Emanuel et al. 1985, Cramer \& Solomon 1993, Leemans \& Solomon 1993). Important changes are also predicted in the functioning of ecosystems (Hunt et al. 1991). There is increasing interest in evaluating the way global change could affect crops and their ability to supply 
food. Modelling the growth of key crops like maize Zea mays L. under changed atmospheric composition and climate is one of the priorities established in the operational plan of the Global Change and Terrestrial Ecosystems (GCTE) core project of the International Geosphere-Biosphere Programme (Steffen et ai. 1992). Parry et al. (1990) pointed out 3 main issues that need to be addressed in considering the likely effects of global change on agriculture; first, the nature of the expected changes in climate; second, the estimated impacts of these changes on crops; and third, the range of appropriate responses to adapt to global change

Argentina is one of the world's largest grain producers. Most of Argentina's grain is produced in the Pampas region (Fig. 1). This region covers approximately 34 million hectares of land of which one third is used for growing grain crops, and the rest for steer fattening and cow-calf operations based upon leys and natural grasslands respectively (Hall et al. 1992) (Fig 1) The Rolling Pampa is the most productive subregion of the Pampas and the area devoted to grain crops varies among years between 50 and $75 \%$ The Rolling Pampa subregion has a temperate humid climate and lacks a dry season. It has an annual rainfall of approximately $1000 \mathrm{~mm}$ and a mean annual temperature of $17^{\circ} \mathrm{C}$. The frost-free period is about $260 \mathrm{~d}$. Soils in the region are mainly Mollisols (INTA 1990 ) developed on a deep mass of Pampean loess (Frenguelli 1925).

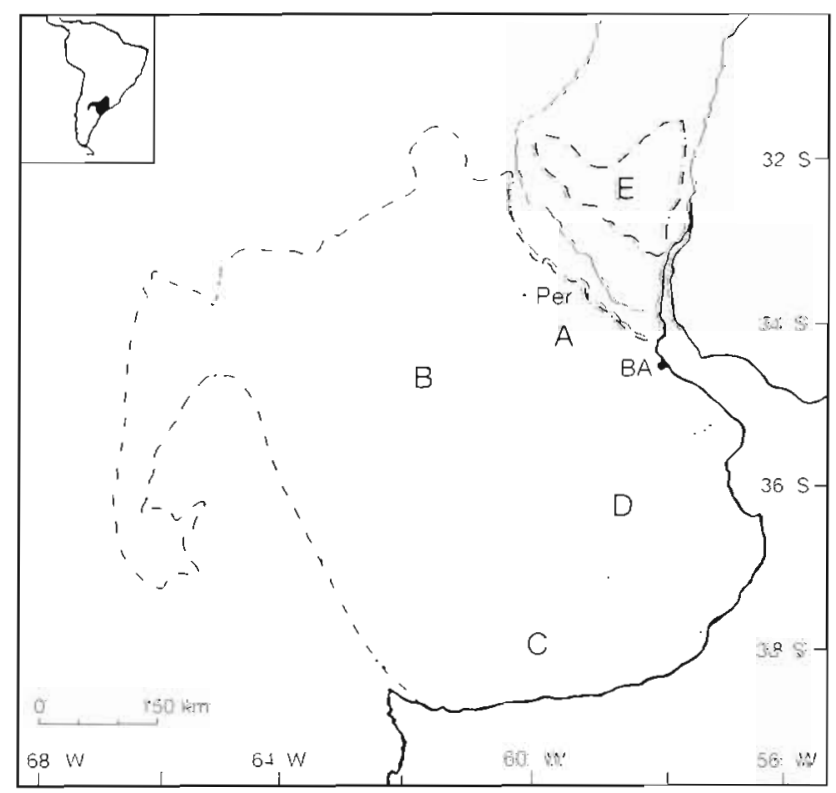

Fig. 1. Potential natural vegetation of the pamperan grasslands A: Rolling Pampa; B: Inland Pampa; (C Southern Pamper, D: Flooding Pampal; E: Mesopotamic Pampa 1---) Boundarie, of the region; $(\cdots \cdot)$ subregions. BA: Buenos Aires; Per: Pergam Adapted trom Leon (1991)
Maize is one of the region's most important crops with 2.3 million hectares (Hall et al. 1992). Its production is concentrated in the northeast of the Rolling Pampa. The average yield of maize in the regjon over the period 1980 to 1992 was 4.6 tha 1 Maize is rotated with wheat and soybean crops.

The objective of this work was to assess the effect of global change upon the yield of maize in the Rolling Pampas of Argentina. To do this we used output data from 3 Global GCMs in conjunction with a crop model.

\section{METHODOLOGY}

We used output from $3 \mathrm{GCM}$ so obtain predictions of the rainfall and temperature patterns for the 'effective'

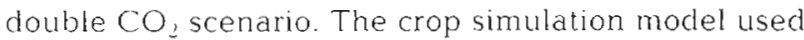
this information to predict the effects of global change upon the behavior of maize. The effective doubling of $\mathrm{CO}$, means an increase in greenhouse gases $\left(\mathrm{CO}_{2}\right.$, $\mathrm{CH}_{4}, \mathrm{~N}_{2} \mathrm{O}, \mathrm{CFC}$ ) producing radiative lorcing equivalent to a doubling of the $\mathrm{CO}_{2}$ concentration. Taking into account the relative rate of increase of the different greenhouse gases, this radiative forcing would be reached at a $\mathrm{CO}$ concentration of $555 \mathrm{ppm}$

As input for the control runs we used weather data recorded by the National Meteorological Service for the town of Pergamino (Lat. $33^{\circ} \mathrm{S}$, Long $60^{\circ} \mathrm{W}$ ) which is a representative location for the climatic conditions of the Rolling Pampa (Fig. 1). We used daily data of precipitation and maximum and minimum temperature for $19 \mathrm{yr}$ corresponding to the period 1960 to 1984 . They represent the only available weather data for the intensive study area of Pergamino. Daily radiation was estimated from sunshine hour data and latitude (Fedes et al. 1978). The GCMs used were: (1) GISS, developed by the Goddard Institute for Space Studies (Hansen et al 1983), (2) GFDL, developed by the Geophysical Fluid Dynamics Laboratory of NOAA (Manabe \& Wetherald 1987), and (3) UKMO, United Kingdom Meteorological Office (Wilson \& Mitchell 1987). GCM output consisted of monthly changes in temperature, precipitation, and radiation. We calculated the climate change scenarios by adding or subtracting the change predicted by the models to the 19 yr weather record used for the control runs (Smith \& Tirpak 1988). This procedure maintained the interannual and dally variability of the historic weather data. Adams et al. (1990) used the same procedure to study the effect of global change on agricultural systems.

The crop model chosen was the Crop Environment Response Synthesis Model (CERES Maize) (Jones \& Kiniry 1986, Ritchie et al. 1989) which has been validated in several regions of the world and proved to represent crop behavior very well under contrasting 
conditions (Hodges et al. 1986). CERES Maize simulates the interaction between environmental factors and plant growth processes of the crop using soil and daily weather data. The main physiological processes simulated by the model are photosynthesis, respiration, phenology, leaf initiation and growth, stem growth, root growth, soil water extraction, evapotianspiration, nitrogen uptake, light interception, grain initiation, and grain growth. As input the model requires dally values of precipitation, maximum and minimum temperature, radiation, soil profile characteristics, planting density, planting date, latitude, and the genetic coefficients for the cultivar Adams et al. (1990) and Cooter (1990) used this model to analyze the effects of global change on agricultural systems in the USA.

The modelling experiments were performed for one of the major soil types of the Rolling Pampa, the Pergamino series. This is a typical Argiudoll with no physical constraints for agriculture. Argiudolls account for more than $85 \%$ of the Rolling Pampa soils (INTA 1990. Hall et al. 1992).

We performed runs for the baseline scenario and for the 3 double- $\mathrm{CO}$, scenarios, accounting for both direct and indirect effects of $\mathrm{CO}_{2}$. To simulate the direct effect of $\mathrm{CO}_{2}$ we increased in the model the efficiency of transformation of light into dry matter by $6 \%$ (Kimball 1983. Cure \& Acock 1986). We simulated modal cultural practices for the Rolling Pampa which are: sowing date around October 15, fallow duration $45 \mathrm{~d}$, between-row distance $70 \mathrm{~cm}$, and density 7 plants $\mathrm{m}^{2}$ In the simulations we used the maize hybrid DAF12 (Dekalb). We selected this hybrid because it was widely used by farmers and because detailed information for model calibration was available ( $\mathrm{J} \mathrm{H}$. Lemcoff unpubl.). The model adequately reproduced the growing season length and yield observed in a detailed field experiment (Lemcoff unpubl.).

Model runs were made assuming an initial soil water content equal to field capacity and a low nitrogen content in the soil $\left(50 \mathrm{~kg} \mathrm{ha}{ }^{-1}\right)$. These are typical conditions for farms with continuous agriculture and without fertilization schedules. We assumed the incorporation of $800 \mathrm{~kg} \mathrm{ha}^{-1}$ of standing dead material at the beginning of the fallow. We also analyzed the performance of maize without nitrogen stress for the GFDL double- $\mathrm{CO}_{2}$ scenario.

A further analysis tested the sensitivity of the maize crop system to climate change. The purpose of this analysis was to assess model response to changes in temperature and precipitation. The experiment consisted in running the model for 3 temperature conditions (control, $+2{ }^{\circ} \mathrm{C}$, and $+4{ }^{\circ} \mathrm{C}$ ) and 3 precipitation conditions (control, $+20 \%,-20 \%$ ).

Finally, we explored some management strategies for adapting current crop systems to future environ- mental conditions. We analyzed the shift in the sowing date under the double-CO, scenario required to match present sowing temperature. In order to analyze the strategy of using new cultivars, we simulated potential new genetic material by modifying, within a biologically plausible range, 3 genetic coefficients related to developmental aspects of the cultivars in CERES Mare The moditied cocfficients were the juvenile phase coefficient, the photoperiodism coefficient, and the grain filling duration coeffucient. The juvenile phase coefficient represents the time period, expressed in degree-days above a base of $8^{\circ} \mathrm{C}$, during which the plants are not responsive to changes in photoperiod. The photoperiodism coefficient corresponds to the extent to which development, expressed in days, is delayed for each hour increase in photoperiod above the longest period at which development proceeds at a maximum rate. The grain filling duration coefficient represents the duration from silking to maturity in degree-days above a base of $8^{\circ} \mathrm{C}$.

\section{RESULTS}

The GISS, GFDL and UKMO GCMs predicted an increase in temperature and precupitation for the region around Pergamino (Fig. 2) There was a good agreement among these GCMs regarding their predictions of medn annual temperature. The models predicted an increase in annual average temperature ranging between 4.2 and $5.2^{\circ} \mathrm{C}$, and agreed in predicting higher increases during summer than winter Annual precipitation projectuons were more variable, ranging from almost no change from present conditions, to a $30 \%$ increase. The 3 models agreed in predicting larger precipitation increases during spring and summer than during winter (Fig. 2).

The increase in temperature and precipitation predicted for a double- $\mathrm{CO}$, scenario resulted in a decrease in the yield of maize for the Rolling Pampa (Fig 3A) This was mainly a result of the shortening of the growing period (Table 1). An increase in temperature triggered maturity stages faster in the climate change scenario than under present conditions. The duration of the sowing-maturity period was shortened by $26 \mathrm{~d}$ on average (Table 1). The direct effect of the increase in $\mathrm{CO}_{2}$ was a small increase in yield that was not enough to compensate for the decrease resulting from the expected changes in climate (Fig 3A). Results of the crop model simulations were similar for the 3 climate change scenarios (Fig 4), in spite of the difterences in total rainfall shown in Fig 2. The joint effects of the changes in $\mathrm{CO}_{2}$ and climate resulted in a reduction in yield of between 20 and $25 \%$ depending on the scenario. 

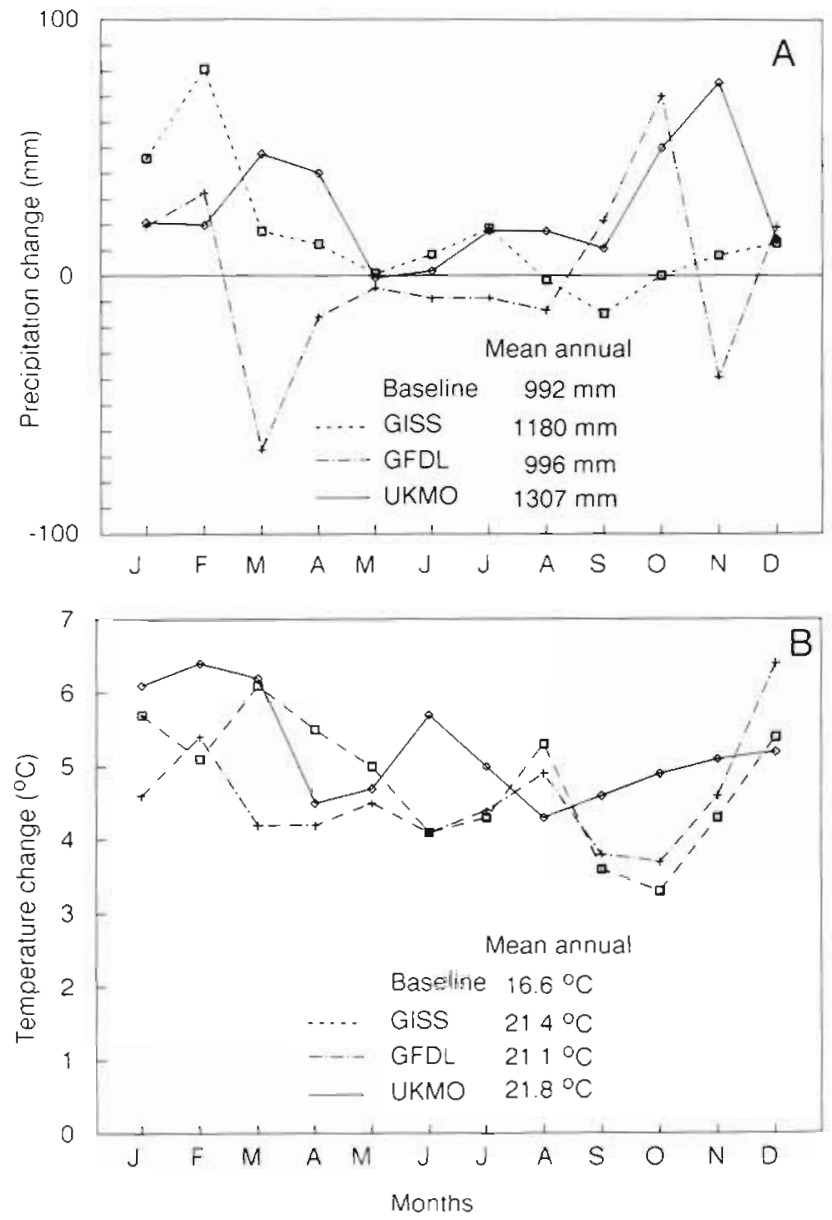

Fig. 2. Variations in (A) rainfall and (B) temperature as a result of climate change for the town of Pergamino as predicted by 3 Cilobal Circulation Models (G(M)

Nitrogen fertilization reduced the difference in yield between the control and the GFDL double- $\mathrm{CO}_{2}$ scenario from 25 to $12 \%$ and resulted in a greater direct effect of the $\mathrm{CO}_{2}$ increase (Fig. 3B). These results agree with observations in which the responses to $\mathrm{CO}_{2}$ fertilization were higher in environments not limited by water and nutrient than in those frequently limited by them (Bazzaz \& Fajer 1992)

In the sensitivity analysis we observed a decrease in yield as a result of the increase in temperature (Table 2) This was accounted for by the decrease in the season length, which particularly affects the grain filling period This period is critical since retranslocation is not quantitatively important in CERES Maize.

The simulated increases in precipitation did not result in increases in yield as we had expected. An explanation may be that with a shorter growing season and smaller plants, water availability did not limit production. The low water stress index in all 3 simulations supports this idea. An increase in precipitation increased the $N$ stress index, as a result of higher $N$ losses under conditions with high precipitation (Table 2)

\section{DISCUSSION}

The major effect of climate change as predicted by this modelling exercise is a decrease in yield resulting from the increase in temperature and the corresponding shortening of the growing period and particularly of the grain filling period. The decrease in yield occurred in spite of the increase in precipitation. Results from Adams et al. (1990), for sites in North America located at similar latitudes to Pergamino (Oklahoma and Texas), also showed that maize production decreased when precipitation increased. In contrast, a simulation analysis for the Southeastern USA region showed that yield and water availability were positively related (Cooter 1990).

Our exercise was limited to assessing the effects of changes in $\mathrm{CO}_{2}$ and climate upon maize yield while maintaining all other variables constant. However, this does not necessarily represent what may actually happen following global change. Farmers will rapidly adapt to the new environmental conditions. Two possible adaptive strategies to cope with the expected climatic change are (1) a shift in the sowing date and (2) a change in cultivars.

One of the strategies suggested is to sow maize early so that the growing period occurs mostly during the cooler part of the year, resulting in a longer growing season. In the climate change scenarios, temperatures similar to those at which maize sowing occurs at present will be reached during July (Fig 5). Alternatively maize could be sown late. In this way the hot months stress index (0) to 1 ) in the vegelative phase, precipitation during the crop growing season and evapotranspiration, for baseline conditions and the 3 climate change scenarios

\begin{tabular}{|c|c|c|c|c|c|}
\hline & & Baseline & GISS & GFDL & UKMO \\
\hline Season length (days) & $\begin{array}{l}\text { Mean } \\
\text { SD }\end{array}$ & $\begin{array}{r}126 \\
8\end{array}$ & $\begin{array}{r}102 \\
4\end{array}$ & $\begin{array}{r}101 \\
4\end{array}$ & $\begin{array}{r}99 \\
3\end{array}$ \\
\hline Water stress & $\begin{array}{l}\text { Mean } \\
\text { SD }\end{array}$ & $\begin{array}{r}0.006 \\
0.02\end{array}$ & $\begin{array}{l}0.002 \\
0.007\end{array}$ & $\begin{array}{l}0 \\
0\end{array}$ & $\begin{array}{l}0 \\
0\end{array}$ \\
\hline Precıpitation (mm) & $\begin{array}{l}\text { Mean } \\
\text { SD }\end{array}$ & $\begin{array}{l}590 \\
144\end{array}$ & $\begin{array}{r}477 \\
94\end{array}$ & $\begin{array}{l}530 \\
1.34\end{array}$ & $\begin{array}{l}594 \\
115\end{array}$ \\
\hline $\mathrm{ET}(\mathrm{mm})$ & $\begin{array}{l}\text { Mean } \\
\text { SD }\end{array}$ & $\begin{array}{r}483 \\
20\end{array}$ & $\begin{array}{r}380 \\
25\end{array}$ & $\begin{array}{r}366 \\
23\end{array}$ & $\begin{array}{r}367 \\
27\end{array}$ \\
\hline
\end{tabular}



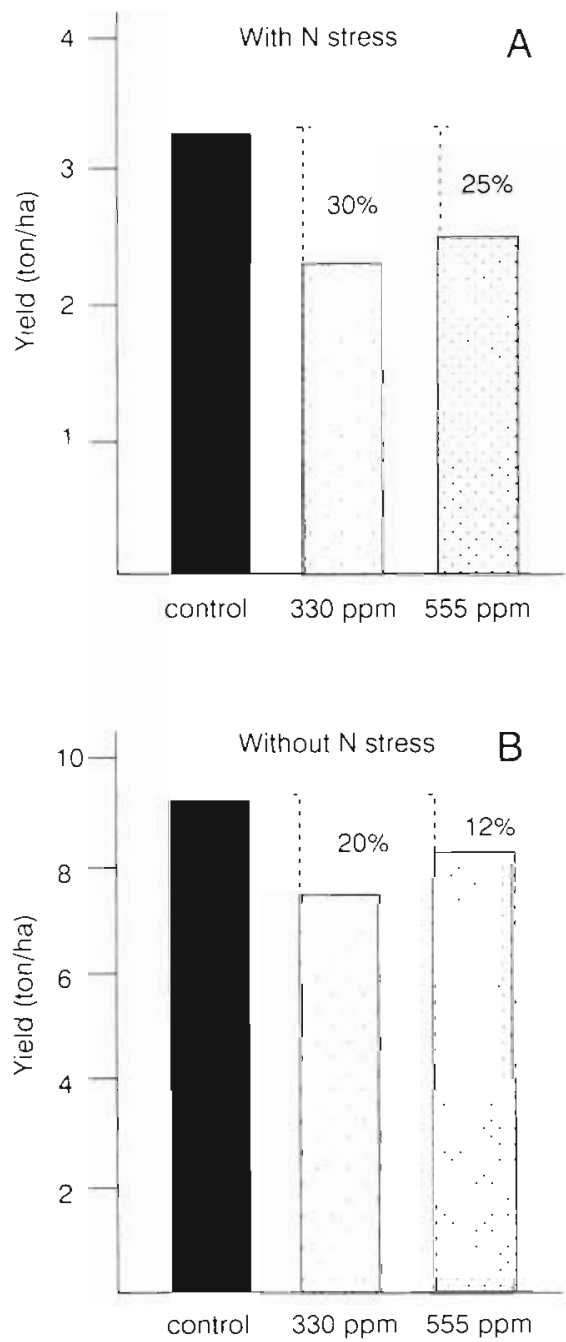

Fig. 3. Effect of climate change alone $(330 \mathrm{ppm})$ and of climate change plus the direct effect of $\mathrm{CO}$, enhancement (555 ppm) on maize yields (A) under nitrogen stress and (B) without nitrogen stress. Black bars: control cross-hatched bars: GFDL climate change scenario with current CO, level (330 ppm) and enhanced $\mathrm{CO}_{2}$ level (555 ppm)

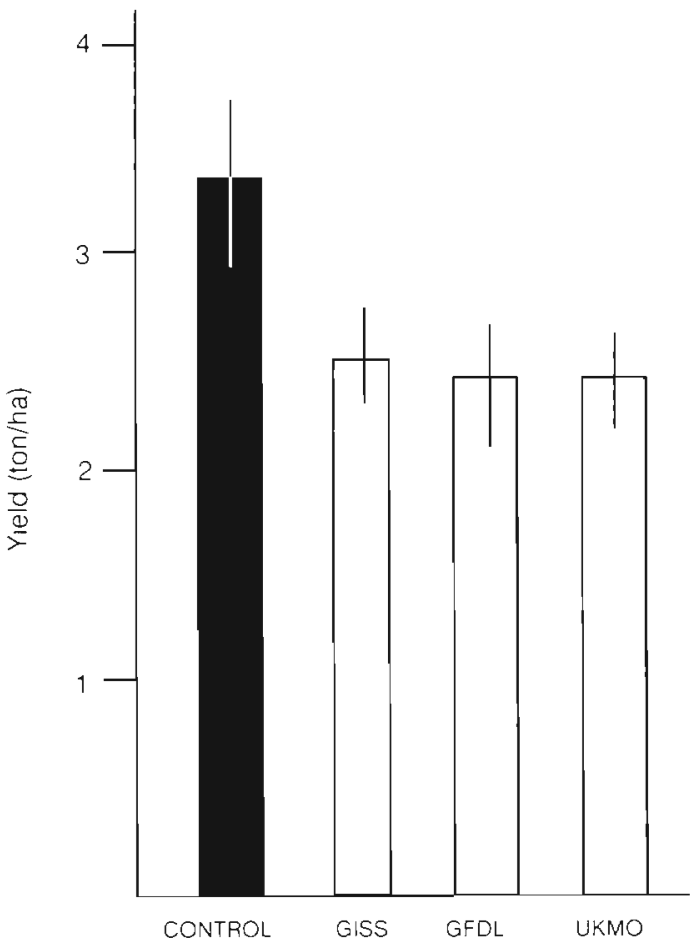

Fig. 4. Effect of changes in $\mathrm{CO}$, concentrations and in clumate as predicted by 3 GCMs (GISS, GFDL, and UKMO) upon mare yleld in the Rolling Pampa. Plotted ylelds are average for 19 yr. Vertical bars are standard deviations

of midsummer are also avoided. Further analysis is needed to evaluate the photoperiodic constraints to modify sowing dates.

An alternative strategy may be to change the cultivar utilized. Results showed that a $20 \%$ increase in the coefficient related to the duration of the grain filling period would be enough to compensate the decrease in yield resulting from climate change (Fig. 6). Modifications of the other coefficients did not result in full yield compensation. Our analysis suggests that by modify-

Table 2. Iffect of changes in temperature and precipitation under elevated $\mathrm{CO}$, conditions upon average maize yıeld, season length, rainfall during crop growing season, nitrogen stress index, nıtrogen losses, and evapotranspiration

\begin{tabular}{|c|c|c|c|c|c|c|c|}
\hline $\begin{array}{c}\text { Raınfall } \\
(\%)\end{array}$ & $\begin{array}{l}\text { Temp. } \\
\left({ }^{\circ} \mathrm{C}\right)\end{array}$ & $\begin{array}{l}\text { Yield } \\
\text { (t ha 1) }\end{array}$ & $\begin{array}{l}\text { Season } \\
\text { length (d) }\end{array}$ & $\begin{array}{l}\text { Rainfall } \\
\text { (mm) }\end{array}$ & $\begin{array}{l}\text { N stress } \\
\text { (veget.) }\end{array}$ & $\begin{array}{c}N \text { losses } \\
\left(\mathrm{kg} \mathrm{ha^{-1 }} \mathrm{d}^{-1}\right)\end{array}$ & $\underset{(\mathrm{mm})}{\mathrm{ET}}$ \\
\hline-20 & 0 & 3.92 & 126 & 488 & 0.31 & 0.12 & 399 \\
\hline-20 & +2 & 3.58 & 113 & 438 & 0.31 & 0.12 & 378 \\
\hline-20 & +4 & 3.52 & 104 & 385 & 0.30 & 0.12 & 366 \\
\hline+0 & 0 & 3.77 & 126 & 611 & 0.34 & 0.17 & 397 \\
\hline+0 & +2 & 3.38 & 113 & 547 & 0.33 & 0.17 & 376 \\
\hline+0 & +4 & 3.35 & 104 & 482 & 0.32 & 0.17 & 364 \\
\hline+20 & 0 & 3.49 & 126 & 733 & 0.37 & 0.22 & 395 \\
\hline+20 & +2 & 3.16 & 113 & 657 & 0.36 & 0.22 & 373 \\
\hline+20 & +4 & 3.12 & 104 & 578 & 0.35 & 0.22 & 360 \\
\hline
\end{tabular}




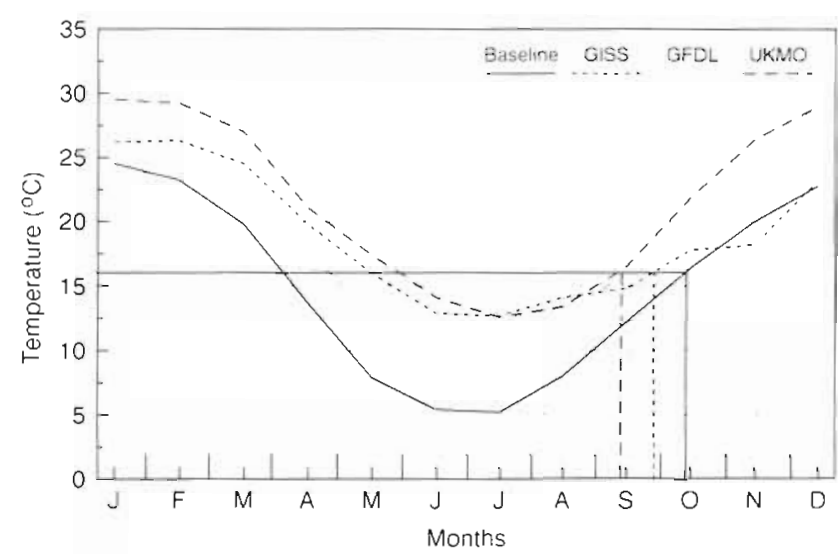

Fig. 5. Mean monthly temperatures for present conditions and for climate change scenarios as predicted by 3 GCMs (GISS. GFDL and UKMO). Vertical lines indicate the time when present sowing temperatures would be reached under each of the 3 climate change scenarios

ing this physiological characteristic, yield under expected climate change conditions may be higher than yield under present conditions. Development of new cultivars adapted to the expected conditions may enable farmers in the Pampas to take advantage of the prolonged growing season and the higher precipitation. Leemans \& Solomon (1993), using a different modelling approach, predicted that temperate maize will be largely replaced by tropical maize in this region. Cultivars with grain filling duration coefficients similar to those used for the hypothetical genotypes are available. However, we have not considered whether they can be easily adapted to the conditions of the Pergamino region (pests, diseases, photoperiod, etc.)

The overall result of this exercise is that maize production in the Rolling Pampa may decrease $25 \%$ as a result of the predicted global change. This result leads to questions relevant to policy and technology development. How much time is required to produce new genotypes? Is it compatible with the expected rate of climate change? Are there other management practices which need to be adjusted to deal with global change conditions?

Our work focused on the core of the current maize producing area. There is a possibility that the response to global change may not be fully compensated towards the warmer boundaries of the present maize region. Leemans \& Solomon (1993) predict that these changes in temperature and precipitation will determine a geographic displacement of the most suitable agroclimatic area for maize. In these circumstances, what will be the needs for irrigation or fertilization? Exploring these productive scenarios will help to improve adjustment of agricultural, social, and economic systems to global change.

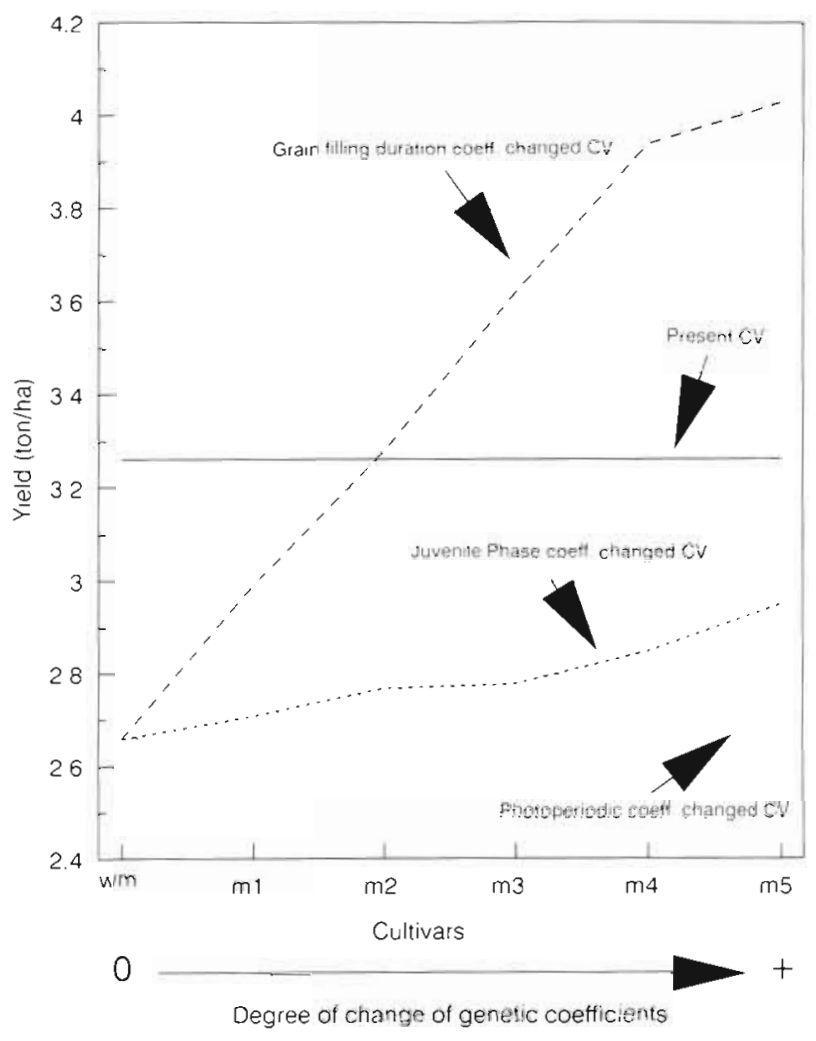

Fig. 6. Simulated yield of hypothetical cultivars in the double $\mathrm{CO}$ scenario predicted by the GFDL model. Cultivars (m1 to m5) were generated by increasing, from 10 to $50 \%$ (a biologIcatly plausible rangel, the Juvenile Phase Coefficient, the Photoperiodic Coefficient and the Gram Filling Duration Confficient of the DAF12 cultuvar. wm: without modifications. Solid line: y'eld of DAF 12 cultivars under present conditions

Acknowledgements. We thank A. J. Hall for helpful comments and J. I L Lemcoff for lending his unpublished data for calıbratıng the CERES model. J. Jones, J. Ritchre, D. Godwin, C. Rosenzweig, A. Iglesias, and B. Curry made important suggestions throughout the development of this project. An anonymous reviewer provided helpful comments which contributed significantly to improving the manuscript. This work was funded by Consejo Nacional de Investigaciones Clentificas), recnicas (Argentina). Fundacion Antorchas, U.S. Invironmental Protection Agency and Columbia Unversity. O.E.S. was partially supported by a Guggenhem fellowship. This work contributes to the Global Change and Terrestrial Ecosystems (GCTE) Core Project of the International Geosphere-Biosphere Programme (IGBP).

\section{LITERATURE CITED}

Adams, R. M., Rosenzweig, C., Peart, R. M., Ritchie, J. T., McCarl, B. A.. Glyer, J. D. Curry, R. B. Jones, J. W., Boote. K. J . Allen, L. H. Jr (1990). Global climate change and US agriculture. Nature 345: 219-224

Bazzaz, F. A., Fajer, E. D. (1992). Plant life in a CO_-rich world Sclent. Am. 266: 68-74

Conter, E J (1990). The impact of climate change on continuous corn production in the southern USA. Clim ('hange 16: $53-82$ 
Cramer, W. P., Solomon, A. M. 1993). Climatic classilication and future global redistribution of agncultural land. Clim Res. 3.97-110

Cure, J D., Acock, B. (1986). Crop responses to carbon dioxide doubling. a literature survey. Agricult. For. Meleorol 38: 127-145

Fedes, R. A, Kowalit, P. J., Zarandy, H. 119781 Simulation of fueld watre use and crop pelds. PUDOC, Wagenngen, 1) 189

Frenguella, J 119251 Loess y limos pampeanos. Anales de la Sociedad Argentina de Estudios Geouraticos GAEA 1:7--41

Emanuel, W R, Shumart, H H., Stovenson, M O. (1985). (limate change and the broad scale distribution of terestrial ecosystems complexes Clim Change 7 29-4.3

Hall, A. J., Rebella, C M., Cihorsa, C M., Culot, J. Ph. (1992). Field crops systoms of the pampas. In: Pearson, C J led.) Ecosystems of the world, Vol 18, Field crop ecosystems of the world. Elsevier. Ansterdam. p. 413-450

Hansen, J., Russell, G., Rind, D., Stone, P., Lacis, A., Lebedeft, S, Ruedy, R., Travis, L. (1983). Efficient threedimensional global models for climate studies: Models I and II. Mon. Weather Rev. 111 , 609-662

Hodges. T., Botner, D., Sakamoto, C.. Hays-Haug, J (1986) Using the CERES Maize model to estimate production for the US corn belt. Agricultural and Forest Meteorology 40 : $293-303$

Hunt, H. W.. Trlica, N1. J., Redente, E F, Moore, J. C, Detling, J. K., Kittel, T. G. F., Walter, D. E., Fowler, M. C., Klein, D A., Elliot, E. T 11991$\}$ Simulation model for the eftects of climate change on temperate grassland ecosystems. Ecol. Modelling 5:3: 205-246

INTA (1990). Atlas de suelos de la República Argentina. Tomo 1. SAGYP, Buenos Aires

Jones, D. A., Kiniry, J R. (1986). CERES-Maizc: a simulation model of maize growth and devolopment. Texas A\&M University Press, College Station

Kumball, B. A. (1983). Carbon droxide and agricultural yeld: an assemblage and analysis of 4.30 prior observations. Agron. J. 75: 779-788

Editor: V. Neentemeyel
Leemans, R., Solomon, A. (1993). Modeling the potential change in yield and distribution of the earth's crops under a warmed climate. Clim. Ros. 3: 79-96

Leon, R. J. C \{1991\} Rio de la Plata grasslands. Vegetation. In Coupland, R. T fed.) Ecosystems of the world, Vol. 8A, Natural grasslands Elsevier, Amstordam, p) 367-407

Manabe, S., Wethelalal, R $T$ 11987). Lalge scale changes in soll wetness induced by an increased in carbon dioxide. J. Atmos. Sci. 44.1211-12:35

Mlooney, H. A., Drake, B. G., Luxmoore, R. J., Oechel, W C.. Pilelka, L. $\Gamma$ (194) 1). Predicung ecosystem responses to alevated ( 0 , concentrations. Buoscience 4 1: 96-104

Parry, M. L., Porter, J. H., Carter, T R. (1990). Agricullure. climate change and its mplications Trends Ecol. Evol. 5: $318-322$

Ramanathan, $V$ (1988) The greenhouse theory of climate change: a test by an inadvertent global experment. Science 24(): 292-29)

Ritchie, J., Singh, U., Codwan, D., Hunt, L. (1989). A user's guide to Ceres Maize - v 2.10. International Fertilizer Development Center, Muscle Shodls, AL

Schneider, S. H. (1989). The greenhouse eftect: science and policy. Science 243: $771-781$

Smith, J. B, Tirpak, D. A. (1988). The potential eftects of global clumate change on the United States. U.S. EPA. Washington, DC

Steffen, W. L, Walker, B H., Ingram, J. S., Koch, G. W. 11992). Global change and terrestrial ecosystems. The operational plan. IGBP Report No. 21 (ICSU). Stockholm

Tissuc, D. T., Oechel, W. C (1987). Response ot Eriophorum raginatum to eluated $\mathrm{CO}$, and temperature in the Alciskan tussock tundra. Ecology 68: 401-410

Wilson, C. A, Mitchell, J. F. B (1987). A doubled CO, clumate sensitivity experiment with a global climate model including a simple ocean. J. geophys. Rts. 92 (D IJ): 13315-13343

Ziska, L. H., Drake, B. G., Chamberlain. S. 1.990). Long-term photosynthetic response in single leaves of a $C_{\text {; }}$ and $C_{+}$ sall marsh species yrown at elevated atmospheric $\mathrm{CO}_{2}$ in situ. Oecologla $83.469-472$

Manuscript tirst received: January $13,190.3$

Revisod version accepted: November 10, 199,3 